\title{
Ergenlik Çağında Özel Gereksinimli Çocuğu Olan Annelerin Aile Stresörleri İle Başa Çıkma Durumlarının İncelenmesi
}

Investigation of the Family Stressors of Mothers who has Child with Special Needs in Adolescence Age

Gizem Yağmur DEĞíRMENCi ${ }^{1}$, Haktan DEMIRCiOĞLU ${ }^{2}$

${ }_{1}^{1}$ Bil.Uz., Hacettepe Üniversitesi Sağlık Bilimleri Fakültesi Çocuk Gelişimi Bölümü, Ankara, Türkiye

${ }^{2}$ Doç.Dr., Hacettepe Üniversitesi Sağlık Bilimleri Fakültesi Çocuk Gelişimi Bölümü, Ankara, Türkiye

\section{öz}

\begin{abstract}
Amaç: Bu çalışmanın amacı ergenlik çağında özel gereksinimli çocuğu olan annelerin aile stresörleri ile başa çıkma durumlarının incelenmesidir. Gereç ve Yöntem: Araştırmanın evreni Ankara ilinde ikamet eden ve ergenlik çağında özel gereksinimliliği bulunan çocukların anneleridir. Çocuğu Ankara ili merkez ilçelerinde bulunan altı özel eğitim mesleki eğitim merkezine devam eden 116 anne araşıımanın çalışma grubunu oluşturmuştur. Araştırmada "Aile Stresörleri Ile Başa Çıkma Yöntemleri Ölçeği”" ve araştırmacılar tarafından geliştirilen "Aile Bilgi Formu" kullanılmıştır. Sonuçlar: Ergenlik çağında özel gereksinimli çocuğu olan annelerin çalışma durumu, yardım alabileceği birinin varlığı, orta yaşta olma, eğitim düzeyi ve hanenin toplam gelir düzeyi ile aile stresörleri ile başa çıkma arasında anlamlı bir ilişki olduğu saptanmıştır $(p<0,05)$. Güncel araştırma sonuçlarına göre ise özel gereksinimliliği bulunan çocuğun yaşı ve cinsiyeti, sahip olunan çocuk sayısı ve engelin türü ile stresörler arasında ise ilişki saptanmamışıtır. Tartışma: Bu durum özel gereksinimli çocuğun ergenlik çağına ulaşıncaya dek annenin geliş̧irdiği stresle başa çıkma mekanizmalarının etkililiği ile açıklanabilirken ergenlik çağında özel gereksinimli çocuğu olan annelerin sosyal destek mekanizmalarının güçlendirilmeye ihtiyacı olduğu düşünülmektedir.
\end{abstract}

Anahtar Kelimeler: Aile üyeleri; Yaşam stresi; Ergenlik

\section{ABSTRACT}

Purpose: The aim of this study is to investigate the coping status of mothers who have children with special needs in adolescence. Material and Methods: The population of the study is the mothers of children who live in Ankara and have special needs. The study group consisted of 116 mothers of children who were being educated at six special education vocational training centers located in Ankara. In the study, "Coping with Family Stressors Methods Scale " and the "Family Information Form" developed by the researchers were used. Results: It was found that there was a significant relationship between working status, presence of someone from whom they could get help, being middle aged and education level of the mothers with coping with family stressors $(p<0.05)$. According to the results of the current research, no relationship was found between the age and sex of the child with special needs, the number of children and the type of disability and the stressors. Conclusion: This can be explained by the effectiveness of the coping mechanisms developed by the mother until the child reaches adolescence, while it is seen that the social support mechanisms of the mothers with special needs children need to be strengthened.

Keywords: Family members; Life stress; Adolescence

Sorumlu Yazar (Corresponding Author): Gizem Yağmur DEĞİRMENCl E-mail: gytuncer@hacettepe.edu.tr 
Aile; üyelerinin karşı karşıya kaldığı gelişimsel görevlerle karakterize olan, yaşam boyu süren, istikrarlı ve gelişen dengedeki kişilerarası bir sistemdir (Erikson, 1980). Bu nedenle ailelerin geçireceği değişimler hem her bir üyesinin geçirdiği bireysel aşamalara hem de ailenin fiziksel, sosyal-duygusal değişimlerine ve kritik olaylara bağlıdır (lacolino, Pellerone, Pace ve ark, 2016). Bu kritik olaylardan biri de şüphesiz aileye yeni bir üyenin yani bebeğin katılmasıdır. Gelişen aile bu yeni üyesiyle birlikte değişime uğrar. Bu süreç çocuğun gelişimsel yetersizliklerinin farkına varılması ile stresli bir duruma doğru ilerler. Aileler çoğu zaman kimden ve nasıl yardım ya da bilgi alacaklarını bilememektedirler. Aile üyeleri gelişimsel yetersizliklerin farkına varılması ve daha sonra çocuğun özel gereksinimliliğin tanımlanması ile bu zamanlarda birçok duygusal ve psikolojik aşamadan geçer. Ebeveynler çoğu zaman özel gereksinimli çocuğunun ihtiyaçlarını karşılamanın ekonomik çıktıları ile diğer aile üyelerinin ihtiyaçlarının karşılanması arasında denge kurmakta zorlanırlar. Sosyal açıdan ise sıklıkla içinde yaşadıkları toplum tarafından dışlanma ve izole edilmeyle karşılaşırlar (Estes, Olson, Sullivan ve ark, 2013; Findler, Klein Jacoby ve Gabis, 2016; Safe, Joosten ve Molineux, 2012).

Aile üyeleri bireyler bazında incelediğinde, anne olmak kadınlar için çoğu zaman fiziksel, psikolojik ve sosyolojik olarak belirgin değişimler yaşanan bir yaşam olayı olarak tanımlanır (Razurel, Bruchon-Schweitzer, Dupanloup ve ark, 2011). Annelerin birincil olarak çocuğa bakım veren kişi olması ya da öyle görülmesi aynı zamanda daha fazla stres yaşamalarına da sebep olmaktadır (Montes ve Halterman, 2007; Rogers ve Hogan, 2003). Birçok güçlükle karşılaşmalarına rağmen annelerin zorluklar karşısında uyum sağlamalarında birçok faktör belirlenmiştir (Pelchat, Levert ve Bourgeois-Guérin, 2009). Bazı anneler özel gereksinimli çocuk yetiştirmeyi çok zorlu ve stresli bulurken bazı anneler ise oldukça pozitif ve başarılı olduklarını düşünmektedir (Hastings, Allen, McDermott ve ark, 2002).

Çocuğun özel gereksinimlilikten etkilenme derecesine göre de değişim gösterdiği bilinen kaygı durumunun aile bireyleri arasında anne tarafından diğer üyelerine göre daha fazla deneyimlendiği görülmektedir (Akmeşe, Mutlu ve Günel, 2007). Özel gereksinimli çocuğa sahip olmanın ebeveynlerin stres, ruh sağlığı ve aile işlevleri gibi bir takım özellikleri üzerinde etkileri olduğu bilinmektedir (Hastings, 2003). Aile üyeleri arasında, iletişim güçlükleri, stres, çocuğun desteklenmesi ya da eğitimi ile ilgili sorumluluk paylaşımında dengesizlikler sebebiyle tükenmişlik görülebilmektedir. Bu bakımdan, özel gereksinimi olan çocuk gibi ailenin diğer üyelerinin de gereksinimleri ortaya çıkmaktadır. Sosyal destek görmeyen anneler stres ve kaygı ile baş etmeye çalışmakta, diğer aile bireyleri ile sağlıklı ilişkiler kurmakta zorlanmakta ve annelerin çevresindeki diğer bireyler ile iletişimini azaltmaktadır (Wallander, Pitt ve Mellins, 1990). Ayrıca, bazı araştırma sonuçları göstermektedir ki özel gereksinimli çocuğa sahip olmanın çocuk için elinden gelenin en iyisini yapma, daha iyi bir kişi olma, yeni beceriler geliştirme ve maneviyatı arttırma gibi sonuçları da bulunmaktadır (Hastings ve ark, 2002).

Anneler ile yapılan araştırmalar sıklıkla çocuğunun özel gereksinimliliği nispeten yeni tanımlanmış olabilecek olan ilk çocukluk yıllarına odaklanmaktadır (Hassall, Rose ve Mcdonald, 2005; Hintermair, 2000; Krstıć ve Oros, 2012). Oysa her bir gelişim dönemi kendine özgü dayanaklar ve problemleri de beraberinde getirmektedir. Bu düşünce üzerinden söz konusu araştırma ile ergenlik çağında özel gereksinimli çocuğu olan annelerin aile stresörleri ile baş etme durumlarının incelenmesi amaçlanmıştır.

\section{GEREÇ VE YÖNTEM}

Bu çalışma, ergenlik çağında özel gereksinimli çocuğu olan annelerin aile stresörleri ile baş etme durumlarının annelerin ve çocuklarının demografik özellikleri üzerinden ortaya konmasını hedeflemektedir. Bu yönü ile araştırma, nicel araştırma yöntemlerinden tarama modeline ve kesitsel tarama desenine göre tasarlanmıştır. Araştırmada kullanılan tarama modeli, geçmişte ya da o anda var olan bir durumu olduğu haliyle yansıtan ve tanımlamayı amaçlayan bir yaklaşımdır (Karasar, 2003).

\section{Çalışma Grubu}

Ankara ili merkez ilçelerinde bulunan özel eğitim mesleki eğitim merkezlerinde eğitimine devam eden ergenlik dönemindeki 116 özel gereksinimli çocuğun annesi araştırmanın çalışma grubunu oluşturmuştur. Bu amaçla Ankara il merkezinde altı özel eğitim mesleki eğitim merkezi belirlenmiştir. Bu okullarda araştırma yapabilmek için gereken izinler Ankara İ Milli Eğitim Müdürlüğünden alınmıştır. Ayrıca çalışmaya katılım gönüllülük esasına göre gerçekleşmiş, katılımcılar çalışmaya dahil olmadan önce onam formu imzalamışlardır. Araştırmanın verileri 1 Eylül-20 Ekim 2018 tarihleri arasında Ankara il merkezinde yer alan altı özel eğitim mesleki eğitim merkezi ziyaret edilerek toplanmıştır. 
Aile Stresörleri İle Başa Çıkma Yöntemleri Ölçeği: Clark Michel, Early ve ark. (2014) tarafından, evli bireylerin aile içerisindeki stres faktörlerine karşı kullandıkları başa çıkma yöntemlerini ölçmek için geliştirilmiştir. Ölçeğin Türkçeye uyarlama çalışması Ekşi, Özdemir-Kemahlı ve Abdullayev (2017) tarafından yapılmıştır. Ölçeğin orijinalinde on beş faktör (görev paylaşımı, programları yenileme, planlama, eşler arası iletişim, aile-iş ayrımı, iş-aile ayrımı, beceriler geliştirme, bilişsel yapılandırma, davranış değiştirme, sosyal destek arama, rahatlama egzersizleri, fiziksel egzersizler, birlik-beraberlik, eşler arası ilgi, bütçeyi ayarlama) doğrulanmıştır. Analizler Türkçe uyarlama çalışmasında bu on beş faktörün korunduğunu göstermektedir. Yapılan güvenilirlik analizleri neticesinde, her bir faktör için iç tutarlılık katsayıları .726-.931 arasında, test-tekrar test korelasyon değerleri .532- .916 arasında olduğu saptanmıştır.

Aile Bilgi Formu: Aile bilgi formu araştırmacılar tarafından geliştirilmiştir ve katılımcılara ait demografik bilgiler yanında çocuğa ait soruları da içermektedir. Ayrıca katılımcıların anne baba ve çocuk haricinde aynı haneyi paylaştıkları kişilerin varlığını ve karşılaştıkları zor durumlarda yardım aldıkları kişilere ait bilgileri de sorgulamaktadır.

İstatistiksel Analiz

Araştırmanın verilerinin analizi öncesinde dağılımın normalliği test edilmiştir. Normal dağılım sergileyen (özel gereksinimliliği bulunan çocuğun cinsiyeti ve yaşı, anneye yardımcı olan birinin olup olmaması ve evde anne baba ve çocuklar dışında sürekli yaşayan birinin olup olmaması) veri dizilimine yönelik ikili karşılaştırmalarda bağımsız gruplar için $t$ testi, üçlü ve daha fazla grubu içeren karşılaştırmalarda (annelerin yaşları, annelerin eğitim durumları, sahip olunan çocuk sayısı, çocuğun sahip olduğu engel türü ve hanenin toplam geliri) ise tek yönlü varyans analizi uygulanmıştır. Normal dağılımın olmadığı veri dizilimine (annelerin çalışma durumu) yönelik ikili karşılaştırmalarda ise Mann-Whitney $U$ testi kullanıımıştır.

\section{SONUÇLAR}

Araştırmaya katılan annelerin demografik bilgileri incelendiğinde, \% 35'inin 40 yaş ve altında, \% 40'ının 41-45 yaş arasında ve $\% 25^{\prime}$ inin ise 46 yaş ve üstünde olduğu; \% 13'ünün okur-yazar, \% 71'inin ilkokulortaokul, \% 15'inin lise ve \% 1'inin yüksekokul mezunu olduğu; \% 92'sinin çalışmadığı, \% 8'inin çalıştığı; \% 67'sinin özel gereksinimli çocuğunun 12-17 yaş arasında ve \% 33'ünün 18-23 yaş arasında olduğu; bu çocukların \% 45'inin kız, \% 55'inin ise erkek olduğu; yine bu çocukların \% 58'inin zihinsel engelli, \% 6'sının işitme engelli, \% 5'inin bedensel engelli, \% 4'ünün down sendromlu, \% 4'ünün otizm spektrum bozukluğu olduğu ve \% 23'ünün çoklu engel grubunda yer aldığı görülmektedir.

Tablo 1. Annelerin Aile Stresörleri ile Başa Çıkma Yöntemleri Ölçeği Alt Boyutları Toplam Puan Ortalamalarının Çocuklarının Cinsiyetine Göre t testi Sonuçları

\begin{tabular}{|c|c|c|c|c|c|c|c|}
\hline Ölçek Alt Boyutları & Cinsiyet & $\mathbf{N}$ & $\mathbf{x}$ & $\mathbf{S}$ & sd & $\mathbf{t}$ & $\mathbf{p}$ \\
\hline \multirow[t]{2}{*}{ Görev paylaşımı } & $\mathrm{KIZ}$ & 52 & 3,2821 & 1,32248 & 114 & , 420 & ,675 \\
\hline & Erkek & 64 & 3,1875 & 1,10135 & & & \\
\hline \multirow[t]{2}{*}{ Programları yenileme } & $\mathrm{K} \mathrm{IZ}$ & 52 & 2,9167 & 1,23647 & 114 & ,381 & ,704 \\
\hline & Erkek & 64 & 2,8281 & 1,25285 & & & \\
\hline \multirow[t]{2}{*}{ Planlama } & $\mathrm{K} ı \mathrm{Z}$ & 52 & 4,3269 & 1,42265 & 114 & $-1,136$ & ,258 \\
\hline & Erkek & 64 & 4,6250 & 1,39095 & & & \\
\hline \multirow[t]{2}{*}{ Eşler arası iletişim } & $\mathrm{K} I \mathrm{Z}$ & 52 & 4,4038 & 1,54573 & 114 &,- 286 & ,776 \\
\hline & Erkek & 64 & 4,4844 & 1,47875 & & & \\
\hline \multirow[t]{2}{*}{ Becerilerini geliştirme } & $\mathrm{K} \mathrm{z}$ & 52 & 3,7821 & 1,22053 & 114 & $-1,173$ & ,243 \\
\hline & Erkek & 64 & 4,0729 & 1,40855 & & & \\
\hline \multirow[t]{2}{*}{ Bilişsel yapılandırma } & $\mathrm{K} \mathrm{IZ}$ & 52 & 4,0769 & 1,47250 & 114 & $-1,442$ & ,152 \\
\hline & Erkek & 64 & 4,4427 & 1,25856 & & & \\
\hline \multirow[t]{2}{*}{ Davranış değiştirme } & $\mathrm{K} \mathrm{IZ}$ & 52 & 3,7885 & 1,15664 & 114 & $-1,626$ & ,107 \\
\hline & Erkek & 64 & 4,1667 & 1,31334 & & & \\
\hline \multirow[t]{2}{*}{ Sosyal destek arama } & $\mathrm{K} ı \mathrm{Z}$ & 52 & 2,5513 & 1,24527 & 114 &,- 435 & ,665 \\
\hline & Erkek & 64 & 2,6667 & 1,55101 & & & \\
\hline \multirow[t]{2}{*}{ Rahatlama egzersizleri } & $\mathrm{K} \mathrm{Iz}$ & 52 & 3,0321 & 1,48524 & 114 & 003 & ,998 \\
\hline & Erkek & 64 & 3,0313 & 1,28856 & & & \\
\hline \multirow[t]{2}{*}{ Fiziksel egzersizler } & $\mathrm{K} \mathrm{Iz}$ & 52 & 2,6603 & 1,45145 & 114 & ,602 &, 548 \\
\hline & Erkek & 64 & 2,5000 & 1,40546 & & & \\
\hline \multirow[t]{2}{*}{ Birlik beraberlik } & $\mathrm{K} \mathrm{Iz}$ & 52 & 3,9359 & 1,47460 & 114 & $-1,251$ & ,213 \\
\hline & Erkek & 64 & 4,2760 & 1,44084 & & & \\
\hline \multirow[t]{2}{*}{ Eşler arası ilgi } & $\mathrm{K} \mathrm{IZ}$ & 52 & 4,0513 & 1,52021 & 114 &,- 409 & ,683 \\
\hline & Erkek & 64 & 4,1771 & 1,74470 & & & \\
\hline \multirow[t]{2}{*}{ Bütçeyi ayarlama } & $\mathrm{K} \mathrm{IZ}$ & 52 & 4,6603 & 1,32923 & 114 &,- 647 &, 519 \\
\hline & Erkek & 64 & 4,8281 & 1,43525 & & & \\
\hline
\end{tabular}


Tablo 1 incelendiğinde, özel gereksinimli çocukların annelerinin aile stresörleri ile başa çıkma yöntemleri ölçeği alt boyutları toplam puan ortalamaları arasında çocuklarının cinsiyetine göre anlamlı farklılık olmadığı görülmektedir.
Tablo 2'ye bakıldığında, özel gereksinimli çocukların annelerinin aile stresörleri ile başa çıkma yöntemleri ölçeği alt boyutları toplam puan ortalamaları arasında çocuklarının yaşlarına göre anlamlı farklılık olmadığı görülmektedir.

Tablo 2. Annelerin Aile Stresörleri ile Başa Çıkma Yöntemleri Ölçeği Alt Boyutları Toplam Puan Ortalamalarının Çocuklarının Yaşlarına Göre t testi Sonuçları

\begin{tabular}{|c|c|c|c|c|c|c|c|}
\hline Ölçek Alt Boyutları & Yaş & $\mathbf{N}$ & $\mathbf{X}$ & $\mathbf{S}$ & sd & $t$ & p \\
\hline \multirow[t]{2}{*}{ Görev paylaşımı } & $12-17$ & 78 & 3,1581 & 1,19610 & 114 &,- 921 & ,359 \\
\hline & $18-23$ & 38 & 3,3772 & 1,21347 & & & \\
\hline \multirow[t]{2}{*}{ Programları yenileme } & $12-17$ & 78 & 2,8077 & 1,23152 & 114 &,- 746 & ,457 \\
\hline & $18-23$ & 38 & 2,9912 & 1,26749 & & & \\
\hline \multirow{2}{*}{ Planlama } & $12-17$ & 78 & 4,4744 & 1,30104 & 114 &,- 186 & ,853 \\
\hline & $18-23$ & 38 & 4,5263 & 1,62124 & & & \\
\hline \multirow[t]{2}{*}{ Eşler arası iletişim } & $12-17$ & 78 & 4,3504 & 1,53167 & 114 & $-1,005$ & ,317 \\
\hline & $18-23$ & 38 & 4,6491 & 1,44144 & & & \\
\hline \multirow[t]{2}{*}{ Becerilerini geliştirme } & $12-17$ & 78 & 3,7863 & 1,33871 & 114 & $-1,831$ & ,070 \\
\hline & $18-23$ & 38 & 4,2632 & 1,26908 & & & \\
\hline \multirow[t]{2}{*}{ Bilişsel yapılandırma } & $12-17$ & 78 & 4,1538 & 1,37772 & 114 & $-1,418$ & ,159 \\
\hline & $18-23$ & 38 & 4,5351 & 1,31870 & & & \\
\hline \multirow[t]{2}{*}{ Davranış değiştirme } & $12-17$ & 78 & 3,8932 & 1,29210 & 114 & $-1,282$ & ,202 \\
\hline & $18-23$ & 38 & 4,2105 & 1,16098 & & & \\
\hline \multirow[t]{2}{*}{ Sosyal destek arama } & $12-17$ & 78 & 2,5256 & 1,43701 & 114 &,- 972 & ,333 \\
\hline & $18-23$ & 38 & 2,7982 & 1,37664 & & & \\
\hline \multirow[t]{2}{*}{ Rahatlama egzersizleri } & $12-17$ & 78 & 2,9231 & 1,43339 & 114 & $-1,221$ & ,224 \\
\hline & $18-23$ & 38 & 3,2544 & 1,23131 & & & \\
\hline \multirow[t]{2}{*}{ Fiziksel egzersizler } & $12-17$ & 78 & 2,4957 & 1,44324 & 114 &,- 825 & ,411 \\
\hline & $18-23$ & 38 & 2,7281 & 1,38385 & & & \\
\hline \multirow[t]{2}{*}{ Birlik beraberlik } & $12-17$ & 78 & 4,0897 & 1,42506 & 114 &,- 356 & ,722 \\
\hline & $18-23$ & 38 & 4,1930 & 1,54537 & & & \\
\hline \multirow[t]{2}{*}{ Eşler arası ilgi } & $12-17$ & 78 & 3,9188 & 1,63404 & 114 & $-1,919$ & ,057 \\
\hline & $18-23$ & 38 & 4,5351 & 1,60056 & & & \\
\hline \multirow[t]{2}{*}{ Bütçeyi ayarlama } & $12-17$ & 78 & 4,6239 & 1,39403 & 114 &,- 921 & ,152 \\
\hline & $18-23$ & 38 & 5,0175 & 1,34666 & & & \\
\hline
\end{tabular}

Tablo 3'ya göre, özel gereksinimli çocukların annelerinin aile stresörleri ile başa çıkma yöntemleri ölçeği alt boyutları toplam puan ortalamaları arasında annelerin yaşlarına göre görev paylaşımı ve programları yenileme alt boyutları haricinde anlamlı bir farklılık yoktur. Her iki alt boyutta da (görev paylaşımı ve programları yenileme) anlamlı farklılığın 41-45 yaş diliminde bulunan anneler lehine olduğu ortaya konmuştur $(p<0,05)$.

Tablo 4'e bakıldığında, özel gereksinimli çocukların annelerinin aile stresörleri ile başa çıkma yöntemleri ölçeği alt boyutları toplam puan ortalamaları arasında çocukların engel türüne göre anlamlı bir farkılığın olmadığı görülmektedir.

Tablo 5 incelendiğinde, özel gereksinimli çocukların annelerinin aile stresörleri ile başa çıkma yöntemleri ölçeği alt boyutları toplam puan ortalamaları arasında sahip olunan çocuk sayısına göre anlamlı bir farklılığın olmadığı görülmektedir.

Tablo 6 incelendiğinde, özel gereksinimli çocukların annelerinin aile stresörleri ile başa çıkma yöntemleri ölçeği alt boyutları toplam puan ortalamaları arasında anne eğitim durumlarına göre görev paylaşımı ve programları yenileme alt boyutlarında anlamlı bir farklılık olduğu görülmektedir $(p<0,05)$.

Tablo 7 incelendiğinde, özel gereksinimli çocukların annelerinin aile stresörleri ile başa çıkma yöntemleri ölçeği alt boyutları toplam puan ortalamaları arasında hanenin gelir durumlarına göre görev paylaşımı, programları yenileme, planlama, sosyal destek arama ve eşler arası ilgi alt boyutlarında anlamlı farkın olduğu, diğer alt boyutlarda ise olmadığı görülmektedir. Anlamlı farklılığa sahip her bir alt boyutta, sonucun daha yüksek gelir düzeyine sahip anneler lehine olduğu ortaya konmuştur $(p<0,05)$. 
Tablo 3. Annelerin Aile Stresörleri ile Başa Çıkma Yöntemleri Ölçeği Alt Boyutları Toplam Puan Ortalamalarının Annelerin Yaşlarına Göre Tek Yönlü Varyans Analizi Sonuçları

\begin{tabular}{|c|c|c|c|c|c|c|c|}
\hline $\begin{array}{l}\text { Ölçek Alt } \\
\text { Boyutları }\end{array}$ & $\begin{array}{l}\text { Varyans } \\
\text { Kaynağı }\end{array}$ & $\begin{array}{l}\text { Kareler } \\
\text { toplamı }\end{array}$ & sd & $\begin{array}{c}\text { Kareler } \\
\text { ortalaması }\end{array}$ & $\mathbf{F}$ & p & Anlamlı fark \\
\hline \multirow{3}{*}{ Görev Paylaşımı } & Gruplararası & 14,007 & 2 & 7,003 & 5,211 &, $007^{*}$ & 40 ve altı/ \\
\hline & Grup içi & 151,863 & 113 & 1,344 & & & $41-45$ \\
\hline & Toplam & 165,870 & 115 & & & & \\
\hline \multirow{3}{*}{$\begin{array}{l}\text { Programları } \\
\text { yenileme }\end{array}$} & Gruplararası & 9,188 & 2 & 4,594 & 3,092 & ,049* & 40 ve altı/ \\
\hline & Grup içi & 167,896 & 113 & 1,486 & & & $41-45$ \\
\hline & Toplam & 177,084 & 115 & & & & \\
\hline \multirow{3}{*}{ Planlama } & Gruplararası & ,805 & 2 & ,403 & ,201 & ,819 & \\
\hline & Grup içi & 226,853 & 113 & 2,008 & & & \\
\hline & Toplam & 227,658 & 115 & & & & \\
\hline \multirow{3}{*}{ Eşler arası iletişim } & Gruplararası & 3,769 & 2 & 1,884 & ,832 &, 438 & \\
\hline & Grup içi & 256,032 & 113 & 2,266 & & & \\
\hline & Toplam & 259,801 & 115 & & & & \\
\hline \multirow{3}{*}{$\begin{array}{l}\text { Becerilerini } \\
\text { geliştirme }\end{array}$} & Gruplararası & 5,338 & 2 & 2,669 & 1,523 & ,223 & \\
\hline & Grup içi & 198,057 & 113 & 1,753 & & & \\
\hline & Toplam & 203,395 & 115 & & & & \\
\hline \multirow{3}{*}{$\begin{array}{l}\text { Bilişsel } \\
\text { yapılandırma }\end{array}$} & Gruplararası & 9,083 & 2 & 4,541 & 2,502 & ,086 & \\
\hline & Grup içi & 205,127 & 113 & 1,815 & & & \\
\hline & Toplam & 214,210 & 115 & & & & \\
\hline \multirow{3}{*}{$\begin{array}{l}\text { Davranış } \\
\text { değiştirme }\end{array}$} & Gruplararası & 5,513 & 2 & 2,756 & 1,775 &, 174 & \\
\hline & Grup içi & 175,486 & 113 & 1,553 & & & \\
\hline & Toplam & 180,999 & 115 & & & & \\
\hline \multirow{3}{*}{$\begin{array}{l}\text { Sosyal destek } \\
\text { arama }\end{array}$} & Gruplararası & 1,553 & 2 & ,777 & ,382 & ,683 & \\
\hline & Grup içi & 229,470 & 113 & 2,031 & & & \\
\hline & Toplam & 231,023 & 115 & & & & \\
\hline \multirow{3}{*}{$\begin{array}{l}\text { Rahatlama } \\
\text { egzersizleri }\end{array}$} & Gruplararası & 3,553 & 2 & 1,776 & ,940 & ,394 & \\
\hline & Grup içi & 213,553 & 113 & 1,890 & & & \\
\hline & Toplam & 217,106 & 115 & & & & \\
\hline \multirow{3}{*}{$\begin{array}{l}\text { Fiziksel } \\
\text { egzersizler }\end{array}$} & Gruplararası & ,808 & 2 & ,404 & , 197 & ,822 & \\
\hline & Grup içi & 231,816 & 113 & 2,051 & & & \\
\hline & Toplam & 232,624 & 115 & & & & \\
\hline \multirow[t]{3}{*}{ Birlik beraberlik } & Gruplararası & 6,109 & 2 & 3,055 & 1,445 & ,240 & \\
\hline & Grup içi & 238,897 & 113 & 2,114 & & & \\
\hline & Toplam & 245,007 & 115 & & & & \\
\hline \multirow[t]{3}{*}{ Eşler arası ilgi } & Gruplararası & 9,669 & 2 & 4,834 & 1,818 & 167 & \\
\hline & Grup içi & 300,419 & 113 & 2,659 & & & \\
\hline & Toplam & 310,088 & 115 & & & & \\
\hline \multirow[t]{3}{*}{ Bütçeyi ayarlama } & Gruplararası & 4,806 & 2 & 2,403 & 1,258 & ,288 & \\
\hline & Grup içi & 215,887 & 113 & 1,911 & & & \\
\hline & Toplam & 220,693 & 115 & & & & \\
\hline
\end{tabular}


Tablo 4. Annelerin Aile Stresörleri ile Başa Çıkma Yöntemleri Ölçeği Alt Boyutları Toplam Puan Ortalamalarının Çocukların Engel Türüne Göre Tek Yönlü Varyans Analizi Sonuçları

\begin{tabular}{|c|c|c|c|c|c|c|}
\hline $\begin{array}{l}\text { Aile Stresörleri ile Başa } \\
\text { Çıkma Yöntemleri Ölçeği }\end{array}$ & $\begin{array}{l}\text { Varyans } \\
\text { Kaynağı }\end{array}$ & $\begin{array}{l}\text { Kareler } \\
\text { toplamı }\end{array}$ & sd & $\begin{array}{c}\text { Kareler } \\
\text { ortalaması }\end{array}$ & $\mathbf{F}$ & $\mathbf{p}$ \\
\hline \multirow{3}{*}{ Görev Paylaşımı } & Gruplararası & 4,917 & 5 & ,983 & ,672 & ,645 \\
\hline & Grup içi & 160,953 & 110 & 1,463 & & \\
\hline & Toplam & 165,870 & 115 & & & \\
\hline \multirow{3}{*}{ Programları yenileme } & Gruplararası & 7,068 & 5 & 1,414 & 915 & ,474 \\
\hline & Grup içi & 170,017 & 110 & 1,546 & & \\
\hline & Toplam & 177,084 & 115 & & & \\
\hline \multirow{3}{*}{ Planlama } & Gruplararası & 10,897 & 5 & 2,179 & 1,106 & ,361 \\
\hline & Grup içi & 216,761 & 110 & 1,971 & & \\
\hline & Toplam & 227,658 & 115 & & & \\
\hline \multirow{3}{*}{ Eşler arası iletişim } & Gruplararası & 14,332 & 5 & 2,866 & 1,284 & ,276 \\
\hline & Grup içi & 245,469 & 110 & 2,232 & & \\
\hline & Toplam & 259,801 & 115 & & & \\
\hline \multirow{3}{*}{ Becerilerini geliştirme } & Gruplararası & 14,273 & 5 & 2,855 & 1,660 & , 150 \\
\hline & Grup içi & 189,121 & 110 & 1,719 & & \\
\hline & Toplam & 203,395 & 115 & & & \\
\hline \multirow{3}{*}{ Bilişsel yapılandırma } & Gruplararası & 14,954 & 5 & 2,991 & 1,651 & ,153 \\
\hline & Grup içi & 199,256 & 110 & 1,811 & & \\
\hline & Toplam & 214,210 & 115 & & & \\
\hline \multirow{3}{*}{ Davranış değiştirme } & Gruplararası & 5,868 & 5 & 1,174 & ,737 & ,597 \\
\hline & Grup içi & 175,131 & 110 & 1,592 & & \\
\hline & Toplam & 180,999 & 115 & & & \\
\hline \multirow{3}{*}{ Sosyal destek arama } & Gruplararası & 7,349 & 5 & 1,470 & ,723 & ,608 \\
\hline & Grup içi & 223,674 & 110 & 2,033 & & \\
\hline & Toplam & 231,023 & 115 & & & \\
\hline \multirow{3}{*}{ Rahatlama egzersizleri } & Gruplararası & 5,757 & 5 & 1,151 & ,599 & ,701 \\
\hline & Grup içi & 211,349 & 110 & 1,921 & & \\
\hline & Toplam & 217,106 & 115 & & & \\
\hline \multirow{3}{*}{ Fiziksel egzersizler } & Gruplararası & 4,022 & 5 & ,804 & ,387 & ,857 \\
\hline & Grup içi & 228,602 & 110 & 2,078 & & \\
\hline & Toplam & 232,624 & 115 & & & \\
\hline \multirow{3}{*}{ Birlik beraberlik } & Gruplararası & 10,773 & 5 & 2,155 & 1,012 & ,414 \\
\hline & Grup içi & 234,234 & 110 & 2,129 & & \\
\hline & Toplam & 245,007 & 115 & & & \\
\hline \multirow{3}{*}{ Eşler arası ilgi } & Gruplararası & 9,365 & 5 & 1,873 & ,685 & ,636 \\
\hline & Grup içi & 300,723 & 110 & 2,734 & & \\
\hline & Toplam & 310,088 & 115 & & & \\
\hline \multirow{3}{*}{ Bütçeyi ayarlama } & Gruplararası & 4,621 & 5 & 924 & ,471 & ,797 \\
\hline & Grup içi & 216,072 & 110 & 1,964 & & \\
\hline & Toplam & 220,693 & 115 & & & \\
\hline
\end{tabular}


Tablo 5. Annelerin Aile Stresörleri ile Başa Çıkma Yöntemleri Ölçeği Alt Boyutları Toplam Puan Ortalamalarının Sahip Oldukları Çocuk Sayısına Göre Tek Yönlü Varyans Analizi Sonuçları

\begin{tabular}{|c|c|c|c|c|c|c|}
\hline $\begin{array}{l}\text { Aile Stresörleri ile Başa } \\
\text { Çıkma Yöntemleri Ölçeği }\end{array}$ & $\begin{array}{l}\text { Varyans } \\
\text { Kaynağı }\end{array}$ & $\begin{array}{l}\text { Kareler } \\
\text { toplamı }\end{array}$ & sd & $\begin{array}{c}\text { Kareler } \\
\text { ortalaması }\end{array}$ & $\mathbf{F}$ & $\mathbf{p}$ \\
\hline \multirow{3}{*}{ Görev Paylaşımı } & Gruplararası & 1,389 & 3 &, 463 &, 315 & ,814 \\
\hline & Grup içi & 164,480 & 112 & 1,469 & & \\
\hline & Toplam & 165,870 & 115 & & & \\
\hline \multirow{3}{*}{ Programları yenileme } & Gruplararası & 2,928 & 3 & ,976 & ,628 &, 599 \\
\hline & Grup içi & 174,156 & 112 & 1,555 & & \\
\hline & Toplam & 177,084 & 115 & & & \\
\hline \multirow{3}{*}{ Planlama } & Gruplararası & 8,113 & 3 & 2,704 & 1,380 & ,253 \\
\hline & Grup içi & 219,545 & 112 & 1,960 & & \\
\hline & Toplam & 227,658 & 115 & & & \\
\hline \multirow{3}{*}{ Eşler arası iletişim } & Gruplararası & 2,184 & 3 & ,728 & ,317 & ,813 \\
\hline & Grup içi & 257,616 & 112 & 2,300 & & \\
\hline & Toplam & 259,801 & 115 & & & \\
\hline \multirow{3}{*}{ Becerilerini geliştirme } & Gruplararası & 4,017 & 3 & 1,339 & ,752 &, 523 \\
\hline & Grup içi & 199,378 & 112 & 1,780 & & \\
\hline & Toplam & 203,395 & 115 & & & \\
\hline \multirow{3}{*}{ Bilişsel yapılandırma } & Gruplararası & 2,520 & 3 & ,840 & ,444 & ,722 \\
\hline & Grup içi & 211,690 & 112 & 1,890 & & \\
\hline & Toplam & 214,210 & 115 & & & \\
\hline \multirow[t]{3}{*}{ Davranış değiştirme } & Gruplararası & 3,933 & 3 & 1,311 & ,829 & ,481 \\
\hline & Grup içi & 177,066 & 112 & 1,581 & & \\
\hline & Toplam & 180,999 & 115 & & & \\
\hline \multirow[t]{3}{*}{ Sosyal destek arama } & Gruplararası & 6,936 & 3 & 2,312 & 1,156 & ,330 \\
\hline & Grup içi & 224,087 & 112 & 2,001 & & \\
\hline & Toplam & 231,023 & 115 & & & \\
\hline \multirow[t]{3}{*}{ Rahatlama egzersizleri } & Gruplararası & 14,081 & 3 & 4,694 & 2,589 & ,056 \\
\hline & Grup içi & 203,025 & 112 & 1,813 & & \\
\hline & Toplam & 217,106 & 115 & & & \\
\hline \multirow[t]{3}{*}{ Fiziksel egzersizler } & Gruplararası & 3,895 & 3 & 1,298 & ,636 &, 594 \\
\hline & Grup içi & 228,729 & 112 & 2,042 & & \\
\hline & Toplam & 232,624 & 115 & & & \\
\hline \multirow[t]{3}{*}{ Birlik beraberlik } & Gruplararası & 2,002 & 3 & ,667 & ,308 & ,820 \\
\hline & Grup içi & 243,005 & 112 & 2,170 & & \\
\hline & Toplam & 245,007 & 115 & & & \\
\hline \multirow[t]{3}{*}{ Eşler arası ilgi } & Gruplararası & 9,379 & 3 & 3,126 & 1,164 & ,327 \\
\hline & Grup içi & 300,709 & 112 & 2,685 & & \\
\hline & Toplam & 310,088 & 115 & & & \\
\hline \multirow[t]{3}{*}{ Bütçeyi ayarlama } & Gruplararası & 11,062 & 3 & 3,687 & 1,970 & ,123 \\
\hline & Grup içi & 209,632 & 112 & 1,872 & & \\
\hline & Toplam & 220,693 & 115 & & & \\
\hline
\end{tabular}


Tablo 6. Annelerin Aile Stresörleri ile Başa Çıkma Yöntemleri Ölçeği Alt Boyutları Toplam Puan Ortalamalarının Annelerin Eğitim Durumuna Göre Tek Yönlü Varyans Analizi Sonuçları

\begin{tabular}{|c|c|c|c|c|c|c|c|}
\hline $\begin{array}{l}\text { Aile Stresörleri ile } \\
\text { Başa Çıkma } \\
\text { Yöntemleri Ölçeği }\end{array}$ & $\begin{array}{l}\text { Varyans } \\
\text { Kaynağı }\end{array}$ & $\begin{array}{l}\text { Kareler } \\
\text { toplamı }\end{array}$ & sd & $\begin{array}{c}\text { Kareler } \\
\text { ortalaması }\end{array}$ & $\mathbf{F}$ & $\mathbf{p}$ & Anlamlı fark \\
\hline \multirow{3}{*}{ Görev Paylaşımı } & Gruplararası & 9,772 & 2 & 4,886 & 3,537 &, $032^{*}$ & Okuryazar / \\
\hline & Grup içi & 156,098 & 113 & 1,381 & & & lise mezunu \\
\hline & Toplam & 165,870 & 115 & & & & \\
\hline \multirow{3}{*}{ Programları yenileme } & Gruplararası & 15,883 & 2 & 7,941 & 5,567 &, $005^{\star}$ & Okuryazar / \\
\hline & Grup içi & 161,202 & 113 & 1,427 & & & $\begin{array}{l}\text { Lise mezunu } \\
\text { İlk ve ortaokul } \\
\text { mezunu/ } \\
\text { Lise mezunu }\end{array}$ \\
\hline & Toplam & 177,084 & 115 & & & & \\
\hline \multirow{3}{*}{ Planlama } & Gruplararası &, 229 & 2 & ,115 & ,057 & ,945 & \\
\hline & Grup içi & 227,429 & 113 & 2,013 & & & \\
\hline & Toplam & 227,658 & 115 & & & & \\
\hline \multirow{3}{*}{ Eşler arası iletişim } & Gruplararası & 12,056 & 2 & 6,028 & 2,749 & ,068 & \\
\hline & Grup içi & 247,745 & 113 & 2,192 & & & \\
\hline & Toplam & 259,801 & 115 & & & & \\
\hline \multirow{3}{*}{ Becerilerini geliştirme } & Gruplararası & 2,337 & 2 & 1,169 & 657 &, 520 & \\
\hline & Grup içi & 201,057 & 113 & 1,779 & & & \\
\hline & Toplam & 203,395 & 115 & & & & \\
\hline \multirow{3}{*}{ Bilişsel yapılandırma } & Gruplararası & 1,580 & 2 & ,790 & ,420 & ,658 & \\
\hline & Grup içi & 212,630 & 113 & 1,882 & & & \\
\hline & Toplam & 214,210 & 115 & & & & \\
\hline \multirow[t]{3}{*}{ Davranış değiştirme } & Gruplararası & 4,266 & 2 & 2,133 & 1,364 & ,260 & \\
\hline & Grup içi & 176,733 & 113 & 1,564 & & & \\
\hline & Toplam & 180,999 & 115 & & & & \\
\hline \multirow[t]{3}{*}{ Sosyal destek arama } & Gruplararası & 5,486 & 2 & 2,743 & 1,374 & ,257 & \\
\hline & Grup içi & 225,537 & 113 & 1,996 & & & \\
\hline & Toplam & 231,023 & 115 & & & & \\
\hline \multirow[t]{3}{*}{ Rahatlama egzersizleri } & Gruplararası &, 216 & 2 & 108 & ,056 &, 945 & \\
\hline & Grup içi & 216,890 & 113 & 1,919 & & & \\
\hline & Toplam & 217,106 & 115 & & & & \\
\hline \multirow[t]{3}{*}{ Fiziksel egzersizler } & Gruplararası & 2,174 & 2 & 1,087 &, 533 &, 588 & \\
\hline & Grup içi & 230,449 & 113 & 2,039 & & & \\
\hline & Toplam & 232,624 & 115 & & & & \\
\hline \multirow[t]{3}{*}{ Birlik beraberlik } & Gruplararası & ,404 & 2 & ,202 & ,093 & ,911 & \\
\hline & Grup içi & 244,603 & 113 & 2,165 & & & \\
\hline & Toplam & 245,007 & 115 & & & & \\
\hline \multirow[t]{3}{*}{ Eşler arası ilgi } & Gruplararası & 10,407 & 2 & 5,203 & 1,962 & ,145 & \\
\hline & Grup içi & 299,681 & 113 & 2,652 & & & \\
\hline & Toplam & 310,088 & 115 & & & & \\
\hline \multirow[t]{3}{*}{ Bütçeyi ayarlama } & Gruplararası & 3,238 & 2 & 1,619 & ,841 & ,434 & \\
\hline & Grup içi & 217,456 & 113 & 1,924 & & & \\
\hline & Toplam & 220,693 & 115 & & & & \\
\hline
\end{tabular}

${ }^{*} p<0,05$ Eğitim düzeyi yüksek gruplar lehine 
Tablo 7. Annelerin Aile Stresörleri ile Başa Çıkma Yöntemleri Ölçeği Alt Boyutları Toplam Puan Ortalamalarının Hanenin Toplam Gelir Durumuna Göre Tek Yönlü Varyans Analizi Sonuçları

\begin{tabular}{|c|c|c|c|c|c|c|c|}
\hline $\begin{array}{l}\text { Aile Stresörleri ile Başa } \\
\text { Çıkma Yöntemleri Ölçeği }\end{array}$ & $\begin{array}{l}\text { Varyans } \\
\text { Kaynağı }\end{array}$ & $\begin{array}{l}\text { Kareler } \\
\text { toplamı }\end{array}$ & sd & $\begin{array}{c}\text { Kareler } \\
\text { ortalaması }\end{array}$ & $\mathbf{F}$ & $\mathbf{p}$ & Anlamlı fark \\
\hline \multirow{3}{*}{ Görev Paylaşımı } & Gruplararası & 15,306 & 2 & 7,653 & \multirow[t]{2}{*}{5,744} & \multirow[t]{2}{*}{, $004^{*}$} & 0-1400TL/ \\
\hline & Grup içi & 150,563 & 113 & 1,332 & & & 1401-3000TL \\
\hline & Toplam & 165,870 & 115 & & & & \\
\hline \multirow{3}{*}{ Programları yenileme } & Gruplararası & 10,943 & 2 & 5,472 & \multirow[t]{2}{*}{3,721} & \multirow[t]{2}{*}{, $027^{*}$} & $0-1400 \mathrm{TL} /$ \\
\hline & Grup içi & 166,141 & 113 & 1,470 & & & 1401-3000TL \\
\hline & Toplam & 177,084 & 115 & & & & \\
\hline \multirow{3}{*}{ Planlama } & Gruplararası & 15,478 & 2 & 7,739 & \multirow[t]{2}{*}{4,121} & \multirow[t]{2}{*}{, $019^{*}$} & 0-1400TL/ \\
\hline & Grup içi & 212,180 & 113 & 1,878 & & & 1401-3000TL \\
\hline & Toplam & 227,658 & 115 & & & & \\
\hline \multirow{3}{*}{ Eşler arası iletişim } & Gruplararası & 6,522 & 2 & 3,261 & \multirow[t]{2}{*}{1,455} & \multirow[t]{2}{*}{,238 } & \\
\hline & Grup içi & 253,279 & 113 & 2,241 & & & \\
\hline & Toplam & 259,801 & 115 & & \multirow{3}{*}{,313 } & \multirow{3}{*}{,732 } & \\
\hline \multirow{3}{*}{ Becerilerini geliştirme } & Gruplararası & 1,120 & 2 &, 560 & & & \\
\hline & Grup içi & 202,275 & 113 & 1,790 & & & \\
\hline & Toplam & 203,395 & 115 & & & & \\
\hline \multirow{3}{*}{ Bilişsel yapılandırma } & Gruplararası & 6,576 & 2 & 3,288 & \multirow[t]{2}{*}{1,789} & \multirow[t]{2}{*}{,172 } & \\
\hline & Grup içi & 207,634 & 113 & 1,837 & & & \\
\hline & Toplam & 214,210 & 115 & & \multirow{3}{*}{,212 } & \multirow{3}{*}{,809 } & \\
\hline \multirow{3}{*}{ Davranış değiştirme } & Gruplararası &, 678 & 2 & ,339 & & & \\
\hline & Grup içi & 180,321 & 113 & 1,596 & & & \\
\hline & Toplam & 180,999 & 115 & & \multirow{3}{*}{3,183} & \multirow{3}{*}{, $045^{*}$} & \\
\hline \multirow{3}{*}{ Sosyal destek arama } & Gruplararası & 12,319 & 2 & 6,160 & & & 0-1400TL/ \\
\hline & Grup içi & 218,704 & 113 & 1,935 & & & 1401-3000TL \\
\hline & Toplam & 231,023 & 115 & & & & \\
\hline \multirow{3}{*}{ Rahatlama egzersizleri } & Gruplararası & 8,833 & 2 & 4,417 & 2,396 & ,096 & \\
\hline & Grup içi & 208,273 & 113 & 1,843 & & & \\
\hline & Toplam & 217,106 & 115 & & & & \\
\hline & Gruplararası & 10,311 & 2 & 5,155 & 2,620 & ,077 & \\
\hline Fiziksel egzersizler & Grup içi & 222,313 & 113 & 1,967 & & & \\
\hline & Toplam & 232,624 & 115 & & & & \\
\hline & Gruplararası & 11,192 & 2 & 5,596 & 2,704 & ,071 & \\
\hline Birlik beraberlik & Grup içi & 233,815 & 113 & 2,069 & & & \\
\hline & Toplam & 245,007 & 115 & & & & \\
\hline & Gruplararası & 21,765 & 2 & 10,882 & 4,265 & ,016* & 0-1400TL/ \\
\hline Eşler arası ilgi & Grup içi & 288,323 & 113 & 2,552 & & & $3001-4500 T L$ \\
\hline & Toplam & 310,088 & 115 & & & & \\
\hline & Gruplararası & 1,278 & 2 & ,639 & ,329 & ,720 & \\
\hline Bütçeyi ayarlama & Grup içi & 219,416 & 113 & 1,942 & & & \\
\hline & Toplam & 220,693 & 115 & & & & \\
\hline
\end{tabular}

Tablo 8 incelendiğinde, özel gereksinimli çocukların annelerinin aile stresörleri ile başa çıkma yöntemleri ölçeği alt boyutları toplam puan ortalamaları arasında annelerin çalışma durumlarına göre görev paylaşımı ve planlama alt boyutları haricinde anlamlı farklılık olmadığı görülmektedir.

Tablo 9 incelendiğinde, özel gereksinimli çocukların annelerinin aile stresörleri ile başa çıkma yöntemleri ölçeği alt boyutları toplam puan ortalamaları arasında eşleri ve çocukları dışında kendilerine destek veren herhangi birinin var olup olmadığı durumuna göre programları yenileme alt boyutunda anlamlı bir farklılık olduğu görülmektedir $(p<0,05)$.
Aile bilgi formunda anne baba ve çocuklar dışında aynı evde sürekli yaşayan bir bireyin olup olmadığı araştırılmıştır. Bu soru ile anneye yardım edebilecek ya da aile üyeleri dışında bakımından sorumlu olunan bir bireyin varlığına ilişkin bilgi alınması amaçlanmıştır. Tablo 10 incelendiğinde, özel gereksinimli çocukların annelerinin aile stresörleri ile başa çıkma yöntemleri ölçeği alt boyutları toplam puan ortalamaları arasında aynı hanede anne baba ve çocuklar dışında yaşayan herhangi birinin var olup olmadığı durumuna göre bilişsel yapılandırma ve fiziksel egzersizler alt boyutlarında anlamlı bir farklılık olduğu görülmektedir. 
Tablo 8. Annelerin Aile Stresörleri ile Başa Çıkma Yöntemleri Ölçeği Alt Boyutları Toplam Puan Ortalamalarının Annelerin Çalışma Durumlarına Göre Mann-Whitney U testi Sonuçları

\begin{tabular}{|c|c|c|c|c|c|c|c|}
\hline Ölçek Alt Boyutları & $\begin{array}{l}\text { Çalışma } \\
\text { Durumu }\end{array}$ & $\mathbf{N}$ & Sıra Ort. & Sıra Top. & $\mathbf{Z}$ & $U$ & $\mathbf{p}$ \\
\hline \multirow[t]{2}{*}{ Görev paylaşımı } & Çalışmıyor & 107 & 60,40 & 6463,00 & & & \\
\hline & Çalışıyor & 9 & 35,89 & 323,00 & 278 & $-2,110$ &, $035^{*}$ \\
\hline \multirow[t]{2}{*}{ Programları yenileme } & Çalışmıyor & 107 & 60,14 & 6434,50 & & & \\
\hline & Çalışıyor & 9 & 39,06 & 351,50 & 306,50 & $-1,815$ &, 065 \\
\hline \multirow[t]{2}{*}{ Planlama } & Çalışmıyor & 107 & 56,55 & 6051,00 & & & \\
\hline & Çalışıyor & 9 & 81,67 & 735,00 & 273 & $-2,167$ &, $030^{*}$ \\
\hline \multirow[t]{2}{*}{ Eşler arası iletişim } & Çalışmıyor & 107 & 57,54 & 6157,00 & & & \\
\hline & Çalışıyor & 9 & 69,89 & 629,00 & 379 & $-1,069$ & ,285 \\
\hline \multirow[t]{2}{*}{ Becerilerini geliştirme } & Çalışmıyor & 107 & 58,47 & 6256,50 & & & \\
\hline & Çalışıyor & 9 & 58,83 & 529,50 & 478,50 & -031 & ,975 \\
\hline \multirow{2}{*}{ Bilişsel yapılandırma } & Çalışmıyor & 107 & 58,42 & 6250,50 & & & \\
\hline & Calısıyor & 9 & 59,50 & 535,50 & 472,50 & -093 & ,926 \\
\hline \multirow{2}{*}{ Davranış değiştirme } & Çalışmıyor & 107 & 58,78 & 6289,00 & & & \\
\hline & Çalışıyor & 9 & 55,22 & 497,00 & 452 & -306 &, 760 \\
\hline \multirow[t]{2}{*}{ Sosyal destek arama } & Çalışmıyor & 107 & 58,66 & 6277,00 & & & \\
\hline & Calısııor & 9 & 56,56 & 509,00 & 464 & -182 & ,856 \\
\hline \multirow[t]{2}{*}{ Rahatlama egzersizleri } & Çalışmıyor & 107 & 57,83 & 6188,00 & & & \\
\hline & Çalışıyor & 9 & 66,44 & 598,00 & 410 & -742 & ,458 \\
\hline \multirow[t]{2}{*}{ Fiziksel egzersizler } & Çalışmıyor & 107 & 57,84 & 6189,00 & & & \\
\hline & Çalışıyor & 9 & 66,33 & 597,00 & 411 & -736 & ,462 \\
\hline \multirow[t]{2}{*}{ Birlik beraberlik } & Çalışmıyor & 107 & 57,07 & 6106,50 & & & \\
\hline & Çalışıyor & 9 & 75,50 & 679,50 & 328,50 & $-1,587$ & ,112 \\
\hline \multirow[t]{2}{*}{ Eşler arası ilgi } & Çalışmıyor & 107 & 57,61 & 6164,00 & & & \\
\hline & Çalışıyor & 9 & 69,11 & 622,00 & 386 & -990 & ,322 \\
\hline \multirow[t]{2}{*}{ Bütçeyi ayarlama } & Çalışmıyor & 107 & 56,98 & 6096,50 & & & \\
\hline & Calısııyor & 9 & 76,61 & 689,50 & 318,50 & $-1,708$ & ,088 \\
\hline
\end{tabular}

Tablo 9. Annelerin Aile Stresörleri ile Başa Çıkma Yöntemleri Ölçeği Alt Boyutları ve Toplam Puan Ortalamalarının Yardımcı Olan Birinin Varlığına Göre t testi Sonuçları

\begin{tabular}{|c|c|c|c|c|c|c|c|}
\hline Ölçek Alt Boyutları & Yardım eden & $\mathbf{N}$ & $\mathbf{X}$ & $\mathbf{S}$ & sd & $\mathbf{t}$ & $\mathbf{p}$ \\
\hline \multirow[t]{2}{*}{ Görev paylaşımı } & Yok & 18 & 3,6667 & 1,29857 & 114 & 1,692 & ,093 \\
\hline & Var & 98 & 3,1497 & 1,17156 & & & \\
\hline \multirow[t]{2}{*}{ Programları yenileme } & Yok & 18 & 3,4259 & 1,28239 & 114 & 2,107 &, $037^{*}$ \\
\hline & Var & 98 & 2,7653 & 1,21201 & & & \\
\hline \multirow[t]{2}{*}{ Planlama } & Yok & 18 & 4,6852 & 1,11714 & 114 & ,634 &, 527 \\
\hline & Var & 98 & 4,4558 & 1,45603 & & & \\
\hline \multirow[t]{2}{*}{ Eşler arası iletişim } & Yok & 18 & 4,6667 & 1,39091 & 114 & ,669 &, 505 \\
\hline & Var & 98 & 4,4082 & 1,52605 & & & \\
\hline \multirow[t]{2}{*}{ Becerilerini geliştirme } & Yok & 18 & 4,0556 & 1,64992 & 114 & ,391 & ,697 \\
\hline & Var & 98 & 3,9218 & 1,27160 & & & \\
\hline \multirow[t]{2}{*}{ Bilişsel yapılandırma } & Yok & 18 & 4,3889 & 1,58527 & 114 & ,371 & ,711 \\
\hline & Var & 98 & 4,2585 & 1,32863 & & & \\
\hline \multirow[t]{2}{*}{ Davranış değiştirme } & Yok & 18 & 3,8148 & 1,45621 & 114 &,- 669 &, 505 \\
\hline & Var & 98 & 4,0306 & 1,21944 & & & \\
\hline \multirow[t]{2}{*}{ Sosyal destek arama } & Yok & 18 & 3,0000 & 1,52538 & 114 & 1,257 & ,211 \\
\hline & Var & 98 & 2,5442 & 1,39331 & & & \\
\hline \multirow[t]{2}{*}{ Rahatlama egzersizleri } & Yok & 18 & 3,1111 & 1,76383 & 114 & ,266 & ,791 \\
\hline & Var & 98 & 3,0170 & 1,30061 & & & \\
\hline \multirow[t]{2}{*}{ Fiziksel egzersizler } & Yok & 18 & 2,7407 & 1,62318 & 114 & ,546 &, 586 \\
\hline & Var & 98 & 2,5408 & 1,38930 & & & \\
\hline \multirow[t]{2}{*}{ Birlik beraberlik } & Yok & 18 & 4,5556 & 1,29857 & 114 & 1,371 & , 173 \\
\hline & Var & 98 & 4,0442 & 1,47963 & & & \\
\hline \multirow[t]{2}{*}{ Eşler arası ilgi } & Yok & 18 & 4,2778 & 1,61791 & 114 &, 440 & ,661 \\
\hline & Var & 98 & 4,0918 & 1,65306 & & & \\
\hline \multirow[t]{2}{*}{ Bütçeyi ayarlama } & Yok & 18 & 4,9630 & 1,26227 & 114 & ,698 & , 486 \\
\hline & Var & 98 & 4,7143 & 1,40935 & & & \\
\hline
\end{tabular}


Tablo 10. Annelerin Aile Stresörleri ile Başa Çıkma Yöntemleri Ölçeği Alt Boyutları Toplam Puan Ortalamalarının Evde Sürekli Yaşayan Birinin Olup Olmamasına Göre t testi Sonuçları

\begin{tabular}{|c|c|c|c|c|c|c|c|}
\hline Ölçek Alt Boyutları & Başka bir fert & $\mathbf{N}$ & $\mathbf{X}$ & $\mathbf{S}$ & sd & $\mathbf{t}$ & p \\
\hline \multirow[t]{2}{*}{ Görev paylaşımı } & Yok & 19 & 3,6140 & 1,33917 & 114 & 1,534 & ,128 \\
\hline & Var & 97 & 3,1546 & 1,16474 & & & \\
\hline \multirow[t]{2}{*}{ Programları yenileme } & Yok & 19 & 3,1930 & 1,38027 & 114 & 1,252 & ,213 \\
\hline & Var & 97 & 2,8041 & 1,20929 & & & \\
\hline \multirow[t]{2}{*}{ Planlama } & Yok & 19 & 4,0000 & 1,44871 & 114 & $-1,678$ & ,096 \\
\hline & Var & 97 & 4,5876 & 1,38592 & & & \\
\hline \multirow[t]{2}{*}{ Eşler arası iletişim } & Yok & 19 & 4,0526 & 1,77869 & 114 & $-1,258$ & ,211 \\
\hline & Var & 97 & 4,5258 & 1,44084 & & & \\
\hline \multirow[t]{2}{*}{ Becerilerini geliştirme } & Yok & 19 & 3,4035 & 1,46388 & 114 & $-1,956$ & ,053 \\
\hline & Var & 97 & 4,0481 & 1,28379 & & & \\
\hline \multirow[t]{2}{*}{ Bilişsel yapılandırma } & Yok & 19 & 3,5789 & 1,36464 & 114 & $-2,499$ & ,014* \\
\hline & Var & 97 & 4,4158 & 1,32901 & & & \\
\hline \multirow[t]{2}{*}{ Davranış değiştirme } & Yok & 19 & 3,6491 & 1,51321 & 114 & $-1,327$ & ,187 \\
\hline & Var & 97 & 4,0653 & 1,19474 & & & \\
\hline \multirow[t]{2}{*}{ Sosyal destek arama } & Yok & 19 & 2,6667 & 1,72848 & 114 & ,173 & ,863 \\
\hline & Var & 97 & 2,6048 & 1,35855 & & & \\
\hline \multirow[t]{2}{*}{ Rahatlama egzersizleri } & Yok & 19 & 2,4912 & 1,24904 & 114 & $-1,896$ & ,061 \\
\hline & Var & 97 & 3,1375 & 1,37837 & & & \\
\hline \multirow[t]{2}{*}{ Fiziksel egzersizler } & Yok & 19 & 1,8772 & 1,08418 & 114 & $-2,375$ & ,019* \\
\hline & Var & 97 & 2,7079 & 1,44518 & & & \\
\hline \multirow[t]{2}{*}{ Birlik beraberlik } & Yok & 19 & 3,5965 & 1,39920 & 114 & $-1,736$ & ,085 \\
\hline & Var & 97 & 4,2268 & 1,45579 & & & \\
\hline \multirow[t]{2}{*}{ Eşler arası ilgi } & Yok & 19 & 3,5439 & 1,71129 & 114 & $-1,688$ & ,094 \\
\hline & Var & 97 & 4,2337 & 1,61314 & & & \\
\hline \multirow[t]{2}{*}{ Bütçeyi ayarlama } & Yok & 19 & 5,0351 & 1,34208 & 114 & 971 & ,334 \\
\hline & Var & 97 & 4,6976 & 1,39367 & & & \\
\hline
\end{tabular}

$\overline{{ }^{*} \mathrm{p}<0,05}$

\section{TARTIŞMA}

Bireylerin ve dolayısı ile ailelerin her bir gelişim dönemi kendine özgü dayanaklar ve problemleri de beraberinde getirmektedir. Erken çocukluk döneminde ve nispeten özel gereksinimliliğin daha yeni tanımlanmış olduğu yıllara odaklanan çalışma sonuçları zaman içerisinde bireylerin ve ailelerin geçirdiği değişimlere ilişkin kısıtlı bilgi sunmaktadır. Güncel araştırma ile ergenlik çağında özel gereksinimli çocuğu olan annelerin aile stresörleri ile baş etme durumlarının incelenmesi amaçlanmıştır.

Özel gereksinimli çocuğa sahip olmak kuşkusuz anne babalar için stresli bir yaşam olayıdır. Nitekim bu durum farklı özel gereksinimlilik türleri arasında da sıklıkla araştırılmıştır. İşitme engelli çocuğu bulunan ebeveynleri konu edinen bir araştırmada anne babalık stresi araştırılmıştır. Sonuçlar sürekli ve yüksek stres puanlarına işaret etmektedir. Ayrıca müdahalelerin yalnızca çocuk temelli olmaması ve ailelerin psikososyal sorunlarını da hedefleyen müdahaleler yapılması önerilmektedir (Hintermair, 2000). Özel gereksinimli çocuğa sahip olma durumunun ebeveynlik stresi üzerindeki etkisini anne ve babalar arasında araştıran ve otizm spektrum bozukluğu olan çocukların anne ve babaların kaygı ve depresyon düzeylerinin karşılaştıııldığı bir çalışmada ise depresyon bakımından anne ve babalar arasında anlamlı bir farklılık saptanmazken kaygı bakımından anneler babalara göre daha fazla kaygı deneyimlemektedirler (Hastings, 2003). Özel gereksinimli çocuğa sahip olmanın stres düzeyi, aile fonksiyonları ve eşler arası ilişkiye olan etkisi ve bu durum ile bağlantılı olarak üç alanın tümünde yüksek stres seviyeleri belirlenmiştir (Dyson, 1997).

Güncel araştırmada elde edilen bilgiler ışığında ergenlik çağında özel gereksinimli çocuğa sahip annelerin aile stresörleri ile başa çıkma durumlarına çocuklarının yaşı ve cinsiyetinin etkili olmadığı saptanmıştır. Bu durum özel gereksinimliliğin nispeten daha yeni tanımlandığı ilk yıllara nazaran çocuğun ilerleyen yaşında annelerin problem çözme konusunda beceriler geliştirmeleriyle açıklanabilir. $\mathrm{Bu}$ bulgu üzerinden özel gereksinimli çocukların cinsiyetinin, annelerinin aile stresörleri ile baş etmede kullandıkları yöntemlerdeki beceri düzeylerini farklılaştırmadığı da söylenebilir.

Özel gereksinimli çocukların ebeveynlerinin aile stresörleri ile başa çıkma yöntemleri ile anne yaşı arasındaki ilişki incelendiğinde görev paylaşımı ve programları yenileme alt boyutlarında 41-45 yaş arası annelerin lehine sonuçlar olduğu görülmektedir. 
Özel gereksinimli çocukların annelerinin aile stresörleri ile başa çıkma yöntemleri ölçeği alt boyutları puanlarının çocukların engel türüne göre tek yönlü varyans analizi sonuçları incelendiğinde engel türünün hiçbir alt boyutta anlamlı farklılık göstermediği yönündedir. Farklı türde özel gereksinimli çocukların ebeveynlerinin katıldığı bir çalışmada otizmli çocukların ebeveynleri, uyum, iletişim ve memnuniyet alanlarında yaygın gelişimsel bozukluğu olan çocukların ebeveynlerinden daha düşük puanlar almıştırlar (lacolino ve ark, 2016). Bulgular arasındaki bu uyumsuzluğu güncel araştırmaya dahil edilen annelerin çoğunlukla zihinsel engelliliği bulunan çocuğa sahip olmalarıyla açıklanabilir.

İlgili literatürde sıklıkla vurgu yapılan sahip olunan çocuk sayısına ilişkin güncel araştırma bulgusu aile stresörleri bakımından anlamlı bir farklıık olmadığı yönündedir. Zihinsel engelli çocuğa sahip olan ebeveynlerin katıldığı yedi yıllık boylamsal bir çalışmada stres, anne babalık kaygıları ve özel gereksinimliliği bulunmayan yaşça küçük çocuğa ilişkin stres incelenmiştir. Araştırma sonuçları özel gereksinimli çocuğa atfedilen stresin özel gereksinimliliği bulunmayan çocuğa göre iki kat daha fazla olduğu saptanmıştır. Bununla birlikte, çoklu regresyon analizi, bir engelsiz kardeşe atfedilen stresin aslında bir engelli aile üyesine atfedilen stresin açıklanmasında varyansın çoğunu açıkladığını ortaya koymuştur (Baxter, Cummins ve Yiolitis, 2000). Sunulan desteğin ya da hizmetin ailenin intiyaçlarına cevap verir biçimde kurgulanması oldukça önemlidir. Otizm spektrum bozukluğu tanısı almış ve altı aylık ev temelli müdahale programına katılan çocukların anneleri ile yapılan bir araştırmada otizme bağlı davranışlar, karşılanmayan aile intiyaçları, kişisel stres düzeyi ve depresyon araştırılmıştır. Çocuğun aldığı destek saati ile annelerin depresif belirti göstermeleri arasında ilişki olduğu görülmüştür. Ancak çocuklarının programa daha fazla katılmış olan anneler daha fazla kişisel baskı yaşadıklarını bildirmiştir (Schwichtenberg ve Poehlmann, 2007).

Çocuğun yaşı ve cinsiyeti kadar sıklıkla araştırılan bir diğer değişken ise sosyo-ekonomik düzeydir. Güncel araştırmada eğitim düzeyi, hanenin toplam geliri ve çalışma durumu ile sosyo-ekonomik durum yordanmaya çalışılmıştır. Çalışma durumlarına göre görev paylaşımı ve planlama alt boyutları haricinde anlamlı farklılık olmadığı görülmektedir. Bu bulgu çerçevesinde, görev paylaşımı alt boyutunda çalışmayan anneler lehine anlamlı farklılığın olması; çalışan annelerin mesai haricinde ev işleri ile ayrıca ilgilenmek zorunda kalmaları ve ev işlerinde yükünü hafifleten bir görev paylaşımına sahip olmamaları ile açıklanabilir. Planlama alt boyutunda çalışan anneler lehine anlamlı farklıı̆ı̆ı olması ise, çocuk bakımının haricinde hem mesai hem de ev işleri gibi sorumluluklara sahip olmanın getirdiği zaruri stres yükünün çalışan annelerce zamanı planlayarak hafifletilmeye çalışılması ile açıklanabilir. Serebral palsili çocukların anneleri ile yapılan bir çalışmada baş etme ve duygusal reaksiyonlar incelenmiş, en çok kullanılan stratejinin yeni bir bakış açısı geliştirmek olduğu görülmüştür. Annelerin başvurduğu stratejiler bakımından çocuğun serebral palsininin şiddeti ve ailenin yaşadığı bölgenin kırsal ya da kentsel oluşu bakımından farkılıı gösterdiği de görülmüştür (Krstıć ve ark, 2012).

Anne eğitim durumu birçok araştırmada ele alınan bir olgudur. Güncel araştırmada elde edilen bilgiler örnekleme dahil edilen anneler arasında lise ve üstü eğitim alma durumun oldukça düşük oranda olduğu görülmüştür. Özellikle eğitim seviyeleri arasındak farkııığa ilişin saptama bakımından görev paylaşma ve programları yenileme alt boyutlarında daha yüksek derecede eğitim alan annelerin lehine sonuçlar sunmaktadır. Illgili literatürde vurgulanan ekonomik düzeyin aile stresörlerine ilişkin etkisinin incelendiği güncel çalışmada yalnızca hanenin aylık toplam geliri ile ilişkisi incelenmiştir. Bulgular görev paylaşımı, planları yenileme, planlama, sosyal destek arama ve eşler arası ilgi alt boyutlarında anlamlı farklılık göstermekte ve aynı zamanda daha yüksek gelirli aileler lehine sonuçlar sergilemektedir. Zihinsel engelli çocuğu olan ve olmayan annelerin sosyo-ekonomik düzeylerinin incelenmesi ve bu durumun anneye psikolojik etkileri üzerine yapılan bir diğer araştırmada ise özel gereksinimli çocuğu olan ailelerin olmayanlara göre ekonomik olarak dezavantajı oldukları belirlenmiştir (Emerson, 2003). IIlgili araştırma sonuçları ile güncel araştırma sonuçlarının tutarlılık gösterdiği görülmektedir.

Epilepsisi olan çocukların anne babalarının baş etme davranışları, sosyal destek ve ruh sağlığı durumlarının incelendiği bir araştırmada sosyal destek ile annelerin anksiyete ve depresyon düzeyleri arasında ilişki bulunmuştur (Carlson ve Miller, 2017). Zihinsel engelliliği bulunan çocukların ebeveynlerinin bilişsel değerlendirmelerinin ailede deneyimlenen stres, baş etme ve çocuk odaklı zorluklara uyum sağlamada önemli etkisi bulunmaktadır. Ebeveynlik bilinci ve stresi, çocuğun mizacı ve aile desteğinin 
araştırıldığı çalışmada aile desteği ile ebeveynlik stresi arasında çok güçlü bir ilişki olduğu görülmüştür (Hassall ve ark, 2005). Otizm spekturum bozukluğu olan çocukların annelerinin depresif duygu durumları ve aile stresörleri on iki yıllık boylamsal bir çalışma ile incelenmiştir. Çocuk ve aile stresi ile annenin depresif duygu durumu arasında kuvvetli bir ilişki bulunmuştur. Ayrıca depresif semptomlar ile fiziksel sağlık arasındaki ilişkiye de dikkat çekilmiştir (Benson, 2018). Risdal ve Singer (2004)'in çalışmasında engelli çocuğu bulunan ebeveynlerin evlilik uyumlarına ilişkin yapılan araştırmaları incelemiştir. Eşlerin evlilik ilişkileri üzerinde özel gereksinimli çocuğa sahip olma durumunun (daha eski varsayımlara göre) beklenenden daha az etkili olduğu görülmüştür.

Özel gereksinimli çocuğa sahip annelerin eşleri ve çocukları dışında kendilerine destek veren herhangi birinin olup olmadığı araştırmada incelenen sosyal destek sistemlerine ait bir diğer durumdur. Annelerin aile stresörleri ile başa çıkma yöntemleri ölçeği alt boyutları toplam puan ortalamaları arasında eşleri ve çocukları dışında kendilerine destek veren herhangi birinin var olup olmadığı durumuna göre programları yenileme alt boyutu haricinde anlamlı farklılık olmadığı görülmektedir. Programları yenileme alt boyutunda, ek bir desteğe sahip olmayanlar lehine çıkan anlamlı farklılık, birincil akrabalar haricinde diğer insanların, yenilenecek programları daha karmaşık hale getirebilme potansiyellerinden kaynaklanmış olabileceği düşünülmektedir. Aynı hanede anne baba ve çocuklar dışında yaşayan herhangi birinin olma durumuna göre aile stresörleri incelendiğinde fiziksel aktivite alt boyutunda anlamı farklılık olduğu saptanmıştır. Bu bilgi özel gereksinimli çocuğa sahip annelerin evde sürekli birlikte yaşadıkları bir bireyin onlara zaman yarattığı bu yolla fiziksel aktivite de bulunabildikleri şeklinde yorumlanabilir.

Sonuç olarak, özel gereksinimli çocuğa sahip olmanın aile stresörleri üzerindeki etkisinin araştırıldığı güncel araştırma sonuçlarına göre sahip olunan çocuğun yaşı ve cinsiyeti, sahip olunan çocuk sayısı ve engelin türü ile stresörler arasında ilişki saptanmamıştır. Bu durum özel gereksinimli çocuğun ergenlik çağına ulaşıncaya dek annenin geliştirdiği stresle başa çıkma mekanizmalarının etkililiği ile açıklanabilir. Ergenlik çağında özel gereksinimli çocuğu olan annelerin çalışma durumu, yardım alabileceği birinin varlığı, orta yaşta olma, eğitim düzeyi ve hanenin gelir düzeyinin aile stresörleri ile başa çıkma üzerinde etkisi olduğu görülmektedir. Bu bakımdan ergenlik çağında özel gereksinimli çocuğu olan annelerin sosyal destek mekanizmalarının güçlendirilmeye intiyacı olduğu düşünülmektedir. Güncel araştırma gibi kesitsel çalışmalarda sunulan bulguların işe koşulması ile yapılandırılacak olan gelecek araştırmalarda çalışmayan, yardım alabilecek birinin bulunmadığı ve yaş aralığı olarak genç ya da ileri yaşlı anneler müdahale programları için seçilebilir. Ayrıca eğitim düzeyi lise ve altı olan anneler ile toplam hane geliri düşük olan grupta yer alan annelere ilişkin sosyal destek sistemlerini güçlendirecek çalışmalara intiyaç duyulduğu görülmektedir.

\section{Kaynaklar}

Akmeşe, P. P., Mutlu, A., \& Günel, M. K. (2007). Serebral paralizili çocukların annelerinin kaygı düzeyinin araştırıması. Çocuk Sağlığı ve Hastalıkları Dergisi, 50, 236-240.

Baxter, C., Cummins, R. A., \& Yiolitis, L. (2000). Journal of Intellectual and developmental disability parental stress attributed to family members with and without disability: a longitudinal study. J Intellect Dev Dıs, 25(2), 105-118.

Benson, P. (2018). The impact of child and family stressors on the self-rated health of mothers of children with autism spectrum disorder: Associations with depressed mood over a 12-year period. Autism, 22(4), 489-501. https://doi.org/10.1177/1362361317697656

Carlson, J. M., \& Miller, P. A. (2017). Family burden, child disability, and the adjustment of mothers caring for children with epilepsy: Role of social support and coping. Epilepsy Behav, 68, 168-173. Elsevier Inc. http://dx.doi.org/10.1016/j.yebeh.2017.01.013

Clark, M. A., Michel, J. S., Early, R. J., \& Baltes, B. B. (2014). Strategies for coping with work stressors and family stressors: scale development and validation. J Bus Psychol, 29(4), 617-638.

Dyson, L. L. (1997). Fathers and mothers of school-age children with developmental disabilities: parental stress, family functioning, and social support. Am J Ment Retard, 102(3),267-279.

Ekşi H., Kemahlı H. P., Abdullayev K. Aile stresörleri ile başa çıkma yöntemleri ölçeği geçerlik ve güvenirlik çalışması, 1. Uluslararası Sosyal Bilimler ve Eğitim Araştırmaları Sempozyumu, 2017.

Emerson, E. (2003). Mothers of children and adolescents with intellectual disability: social and economic situation, mental health status, and the self-assessed social and psychological impact of the child's difficulties. J Intell Disabil Res, 47(4-5), 385-399. Wiley/Blackwell (10.1111). http://doi.wiley.com/10.1046/j.1365-2788.2003.00498.x

Erikson, E. H. (1980). Identity and Life Cycle. New York, NY, US: W W Norton \&Co.

Estes, A., Olson, E., Sullivan, K., Greenson, J., Winter, J., Dawson, G., \& Munson, J. (2013). Parenting-related stress and psychological distress in mothers of toddlers with autism 
spectrum disorders. Braın Dev-Jpn, 35(2), 133-138. http://dx.doi.org/10.1016/j.braindev.2012.10.004

Findler, L., Klein Jacoby, A., \& Gabis, L. (2016). Subjective happiness among mothers of children with disabilities: The role of stress, attachment, guilt and social support. Res Dev Disabil, 55, 44-54. Elsevier Ltd. http://dx.doi.org/10.1016/j.ridd.2016.03.006

Hassall, R., Rose, J., \& McDonald, J. (2005). Parenting stress in mothers of children with an intellectual disability: the effects of parental cognitions in relation to child characteristics and family support. J Intell Disabil Res, 49(6), 405-418. Wiley/Blackwell (10.1111). http://doi.wiley.com/10.1111/j.1365-2788.2005.00673.x

Hastings, R. P., Allen, R., McDermott, K., \& Still, D. (2002). Factors related to positive perceptions in mothers of children with intellectual disabilities. J Appl Res Intellect, 15(3), 269-275.

Hastings, R. P. (2003). Child behaviour problems and partner mental health as correlates of stress in mothers and fathers of children with autism. J Intell Dısabil Res, 47(4-5), 231-7. http://www.ncbi.nlm.nih.gov/pubmed/12787155

Hintermair, M. (2000). Children who are hearing ımpaired with additional aspects of parental stress. Except Children,66(3), 327-332. http://journals.sagepub.com/doi/pdf/10.1177/0014402 90006600304

lacolino, C., Pellerone, M., Pace, U., Ramaci, T., \& Castorina, V. (2016). Family Functioning and Disability: a Study on Italian Parents of Disabled Children. The Europen Proceedings of Social and Behavioural Sciences, Special Is, 39-52. http://dx.doi.org/10.15405/epsbs.2016.05.5

Karasar, N. (2003). Bilimsel Araştırma Yöntemleri. Ankara: Pegem Akademi.

Krstıć, T., \& Oros, M. (2012). Coping with Stress and Adaptation in Mothers of Children with Cerebral Palsy. Med Pregl, 9(10), 373-377. http://www.doiserbia.nb.rs/img/doi/00258105/2012/0025-81051210373K.pdf

Montes, G., \& Halterman, J. S. (2007). Psychological functioning and coping among mothers of children with autism: a population-based study. Pediatrics, 119(5), e1040-6.

http://pediatrics.aappublications.org/content/119/5/e1 040.full.pdf

Pelchat, D., Levert, M.J., \& Bourgeois-Guérin, V. (2009). How do mothers and fathers who have a child with a disability describe their adaptation/ transformation process? J Child Health Care, 13(3), 239-259. http://www.ncbi.nlm.nih.gov/pubmed/19713407

Razurel, C., Bruchon-Schweitzer, M., Dupanloup, A., Irion, O., \& Epiney, M. (2011). Stressful events, social support and coping strategies of primiparous women during the postpartum period: A qualitative study. Midwifery, 27(2), 237-242. Elsevier. http://dx.doi.org/10.1016/j.midw.2009.06.005

Risdal, D., \& Singer, G. H. S. (2004). Marital adjustment in parents of children with disabilities: a historical review and meta-analysis. Res Pract Pers Sev D, 29(2), 95103.http://journals.sagepub.com/doi/pdf/10.2511/rpsd. 29.2 .95
Rogers, M. L., \& Hogan, D. P. (2003). Family life with children with disabilities: the key role of rehabilitation. J Marriage Fam, 65(November), 818-833.

Safe, A., Joosten, A., \& Molineux, M. (2012). The experiences of mothers of children with autism: Managing multiple roles. $J$ Intellect Dev Disabil, 37(4), 294-302. http://www.tandfonline.com/doi/abs/10.3109/13668250.201 $2.736614 \% 5$ Cnhttp://booksc.org/book/21296475

Schwichtenberg, A. J., \& Poehlmann, J. (2007). Applied behaviour analysis: Does intervention intensity relate to family stressors and maternal well-being? J Intell Disabil Res, 51(8), 598605.

Wallander, J. L., Pitt, L. C., \& Mellins, C. A. (1990). Child functional independence and maternal psychosocial stress as risk factors threatening adaptation in mothers of physically or sensorially handicapped children. J Consult Clın Psych, 58(6), 818-824.

http://doi.apa.org/getdoi.cfm?doi=10.1037/0022-

006X.58.6.818 